\title{
Correction - Systematic review and meta-analysis of tumor biomarkers in predicting prognosis in esophageal cancer
}

\author{
Meilan Chen, Jizheng Huang, Zhenli Zhu, Jun Zhang and Ke Li
}

\section{Correction}

After publication of this article (1) we noted errors in the references. The term 'Fau' with varying initials has been included amongst the names of the authors in about a half of the citations, while the fist author of these articles has been omitted. A corrected reference list can be found below:

1. Jemal A, Bray F, Center MM, Ferlay J, Ward E, Forman D: Global cancer statistics. CA Canc J Clin 2011, 61:69-90.

2. Kollarova H, Machova L, Horakova D, Janoutova G, Janout V: Epidemiology of esophageal cancer-an overview article. Biomed Papers Med Faculty University Palacky Olomouc Czechoslovakia 2007, 151:17-20.

3. Simard EP, Ward EM, Siegel R, Jemal A: Cancers with increasing incidence trends in the United States: 1999 through 2008. LID - 10.3322/caac.20141 [doi]. CA Canc J Clin 2012, 4:20141.

4. Vial M, Grande L, Pera M: Epidemiology of adenocarcinoma of the esophagus, gastric cardia, and upper gastric third. Recent Results Canc Res 2010, 182:1-17.

5. Gavin AT, Francisci S, Foschi R, Donnelly DW, Lemmens V, Brenner $H$, Anderson LA: Oesophageal cancer survival in Europe: A EUROCARE-4 study. Canc Epidemiol 2012, 36:505-512.

6. Cen P, Banki F, Cheng L, Khalil K, Du XL, Fallon M, Amato RJ, Kaiser LR: Changes in age, stage distribution, and survival of patients with esophageal adenocarcinoma over three decades in the United States. Ann Surg Oncol 2012, 19:1685-1691.

7. Merkow RP, Bilimoria KY, McCarter MD, Chow WB, Gordon HS, Stewart AK, Ko CY, Bentrem DJ: Effect of histologic subtype on treatment and outcomes

\footnotetext{
* Correspondence: kli@stu.edu.cn

Department of Preventive Medicine, Shantou University Medical College, No.22 Xinling Road, Shantou, Guangdong 515041, China
}

for esophageal cancer in the United States. Cancer 2012, 118:3268-3276.

8. Blom RL, Lagarde SM, Klinkenbijl JHG, Busch OR, van Berge Henegouwen MI: A high body mass index in esophageal cancer patients does not influence postoperative outcome or long-term survival. Ann Surg Oncol 2012, 19:766-771. Epub 2011 Oct 2017.

9. McShane LM, Altman DG, Sauerbrei W, Taube SE, Gion M, Clark GM: REporting recommendations for tumour MARKer prognostic studies (REMARK). $\mathrm{Br} J$ Cancer 2005, 93:387-391.

10. Altman DG: Systematic reviews of evaluations of prognostic variables. BMJ 2001, 323:224-228.

11. Steels E, Paesmans M, Berghmans T, Branle F, Lemaitre F, Mascaux C, Meert AP, Vallot F, Lafitte JJ, Sculier JP: Role of $\mathbf{p 5 3}$ as a prognostic factor for survival in lung cancer: a systematic review of the literature with a meta-analysis. Eur Respir J 2001, 18:705-719.

12. Hanahan D, Weinberg RA: Hallmarks of cancer: the next generation. Cell 2011, 144:646-674.

13. DerSimonian R, Laird N: Meta-analysis in clinical trials. Contr Clin Trials 1986, 7:177-188.

14. Higgins JP, Thompson SG, Deeks JJ, Altman DG: Measuring inconsistency in meta-analyses. BMJ 2003, 327:557-560.

15. Begg CB, Mazumdar M: Operating characteristics of a rank correlation test for publication bias. Biometrics 1994, 50:1088-1101.

16. Song F, Gilbody S: Bias in meta-analysis detected by a simple, graphical test. Increase in studies of publication bias coincided with increasing use of meta-analysis. $B M J 1998, \mathbf{3 1 6}$ :471.

17. Egger M, Davey Smith G, Schneider M, Minder C: Bias in meta-analysis detected by a simple, graphical test. BMJ 1997, 315:629-634.

18. Nabeya Y, Shimada H, Okazumi S, Matsubara H, Gunji Y, Suzuki T, Ochiai T: Serum cross-linked carboxyterminal telopeptide of type I collagen (ICTP) 
as a prognostic tumor marker in patients with esophageal squamous cell carcinoma. Cancer 2002, 94:940-949.

19. Yoon HH, Shi Q, Sukov WR, Wiktor AE, Khan M, Sattler CA , Grothey A, Wu T-T, Diasio RB, Jenkins RB, Sinicrope FA: Association of HER2/ErbB2 expression and gene amplification with pathologic features and prognosis in esophageal adenocarcinomas. Clin Cancer Res 2012, 18:546-554.

20. Buskens CJ, Van Rees BP, Sivula A, Reitsma JB, Haglund C, Bosma PJ, Offerhaus GJ, Van Lanschot JJ, Ristimaki A: Prognostic significance of elevated cyclooxygenase 2 expression in patients with adenocarcinoma of the esophagus. Gastroenterology 2002, 122:1800-1807.

21. Nozoe T, Ezaki T, Kabashima A, Baba H, Maehara Y: Significance of immunohistochemical expression of cyclooxygenase- 2 in squamous cell carcinoma of the esophagus. Am J Surg 2005, 189:110-115.

22. Sivula A, Buskens CJ, van Rees BP, Haglund C, Offerhaus GJ, van Lanschot JJ, Ristimaki A: Prognostic role of cyclooxygenase-2 in neoadjuvant-treated patients with squamous cell carcinoma of the esophagus. Int J Canc J Int Canc 2005, 116:903-908.

23. Bhandari P, Bateman AC, Mehta RL, Stacey BS, Johnson P, Cree IA, Di Nicolantonio F, Patel P: Prognostic significance of cyclooxygenase-2 (COX-2) expression in patients with surgically resectable adenocarcinoma of the oesophagus. BMC Canc 2006, 6:134.

24. Yoon MS, Nam T-K, Lee J-S, Cho S-H, Song J-Y, Ahn S-J, Chung I-J, Jeong J-U, Chung W-K, Nah B-S: VEGF as a predictor for response to definitive chemoradiotherapy and $\mathrm{COX}-2$ as a prognosticator for survival in esophageal squamous cell carcinoma. $J$ Korean Med Sci 2011, 26:513-520. Epub 2011 Mar 2028.

25. Huang JX, Chen WC, Lin M, Zhang YL, Li FY, Song ZX, Xiao W, Chen P, Qian RY, Salminen E, Yu H: Clinicopathological significance of cyclooxygenase-2 and cell cycle-regulatory proteins expression in patients with esophageal squamous cell carcinoma. Dis Esophagus Off J Int Soc Dis Esophagus / ISDE 2012, 25:121-129.

26. Uchida S, Shimada Y, Watanabe G, Tanaka H, Shibagaki $\mathrm{I}$, Miyahara $\mathrm{T}$, Ishigami $\mathrm{S}$, Imamura $\mathrm{M}$ : In oesophageal squamous cell carcinoma vascular endothelial growth factor is associated with p53 mutation, advanced stage and poor prognosis. Br J Cancer 1998, 77:1704-1709.

27. Shimada $Y$, Imamura $M$, Watanabe G, Uchida S, Harada $\mathrm{H}$, Makino T, Kano M: Prognostic factors of oesophageal squamous cell carcinoma from the perspective of molecular biology. Br J Cancer 1999, 80:1281-1288.

28. Shih CH, Ozawa S, Ando N, Ueda M, Kitajima M: Vascular endothelial growth factor expression predicts outcome and lymph node metastasis in squamous cell carcinoma of the esophagus. Clin Canc Res Offic J Am Assoc Canc Res 2000, 6:1161-1168.

29. Shimada H, Takeda A, Nabeya Y, Okazumi SI, Matsubara H, Funami Y, Hayashi H, Gunji Y, Kobayashi $\mathrm{S}$, Suzuki T, Ochiai T: Clinical significance of serum vascular endothelial growth factor in esophageal squamous cell carcinoma. Cancer 2001, 92:663-669.

30. Ahn MJ, Jang SJ, Park YW, Choi JH, Oh HS, Lee $\mathrm{CB}$, Paik HK, Park CK: Clinical prognostic values of vascular endothelial growth factor, microvessel density, and p53 expression in esophageal carcinomas. $J$ Kor Med Sci 2002, 17:201-207.

31. Kato H, Yoshikawa M, Miyazaki T, Nakajima M, Fukai Y, Masuda N, Fukuchi M, Manda R, Tsukada K, Kuwano $\mathrm{H}$ : Expression of vascular endothelial growth factor (VEGF) and its receptors (Flt-1 and Flk-1) in esophageal squamous cell carcinoma. Anticancer Res 2002, 22:3977-3984.

32. Shimada H, Hoshino T, Okazumi S, Matsubara H, Funami Y, Nabeya Y, Hayashi H, Takeda A, Shiratori T, Uno $\mathrm{T}$, et al.: Expression of angiogenic factors predicts response to chemoradiotherapy and prognosis of oesophageal squamous cell carcinoma. Br J Canc 2002, 86:552-557.

33. Ogata Y, Fujita H, Yamana H, Sueyoshi S, Shirouzu $\mathrm{K}$ : Expression of vascular endothelial growth factor as a prognostic factor in node-positive squamous cell carcinoma in the thoracic esophagus: long-term follow-up study. World J Surg 2003, 27:584-589. Epub 2003 Apr 2028.

34. Rosa AR, Schirmer CC, Gurski RR, Meurer L, Edelweiss MI, Kruel CD: Prognostic value of p53 protein expression and vascular endothelial growth factor expression in resected squamous cell carcinoma of the esophagus. Dis Esophagus Offic J Int Soc Dis Esophagus / ISDE 2003, 16:112-118.

35. Dreilich M, Wagenius G, Bergstrom S, Brattstrom D, Larsson A, Hesselius P, Bergqvist M: The role of cystatin $C$ and the angiogenic cytokines VEGF and bFGF in patients with esophageal carcinoma. Med Oncol 2005, 22:29-38.

36. Choi JY, Jang KT, Shim YM, Kim K, Ahn G, Lee KH, Choi Y, Choe YS, Kim BT: Prognostic significance of vascular endothelial growth factor expression and microvessel density in esophageal squamous cell carcinoma: comparison with positron emission tomography. Ann Surg Oncol 2006, 13:1054-1062.

37. Kii T, Takiuchi H, Kawabe S, Gotoh M, Ohta S, Tanaka T, Kuwakado S, Nishitani H, Katsu K: Evaluation of prognostic factors of esophageal squamous cell carcinoma (stage II-III) after concurrent chemoradiotherapy using biopsy specimens. Jpn J Clin Oncol 2007, 37:583-589. 
38. Inoue A, Moriya H, Katada N, Tanabe S, Kobayashi N, Watanabe M, Okayasu I, Ohbu M: Intratumoral lymphangiogenesis of esophageal squamous cell carcinoma and relationship with regulatory factors and prognosis. Pathol Int 2008, 58:611-619.

39. Tzao C, Lee S-C, Tung H-J, Hsu H-S , Hsu W-H, Sun G-H, Yu C-P, Jin J-S, Cheng YL: Expression of hypoxia-inducible factor (HIF)-1alpha and vascular endothelial growth factor (VEGF)-D as outcome predictors in resected esophageal squamous cell carcinoma. Dis Markers 2008, 25:141-148.

40. Cavazzola L, Rosa ARP, Schirmer CC, Gurski RR, Telles JPB, Mielke F, Meurer L, Edelweiss MIA, Kruel CD: Immunohistochemical evaluation for P53 and VEGF (Vascular Endothelial Growth Factor) is not prognostic for long term survival in end stage esophageal adenocarcinoma. Rev Col Bras Cir 2009, 36:24-34.

41. Liu P, Chen W, Zhu H, Liu B, Song S, Shen W, Wang F, Tucker S, Zhong B, Wang D: Expression of VEGF-C correlates with a poor prognosis based on analysis of prognostic factors in 73 patients with esophageal squamous cell carcinomas. Jpn J Clin Oncol 2009, 39:644-650.

42. Kozlowski M, Kowalczuk O, Milewski R, Chyczewski L, Niklinski J, Laudanski J: Serum vascular endothelial growth factors $\mathbf{C}$ and $\mathrm{D}$ in patients with oesophageal cancer. Eur J Cardio-thoracic Surg Offic J Eur Assoc Cardio-thoracic Surg 2010, 38:260-267.

43. Tanaka T, Ishiguro H, Kuwabara Y, Kimura M, Mitsui A, Katada T, Shiozaki M, Naganawa Y, Fujii Y, Takeyama $\mathrm{H}$ : Vascular endothelial growth factor C (VEGF-C) in esophageal cancer correlates with lymph node metastasis and poor patient prognosis. J Exp Clin Canc Res: CR 2010, 29:83.

44. Sun ZG, Wang Z, Liu XY, Liu FY: Mucin 1 and vascular endothelial growth factor $\mathrm{C}$ expression correlates with lymph node metastatic recurrence in patients with NO esophageal cancer after Ivor-Lewis esophagectomy. World J Surg 2011, 35:70-77.

45. Mega S, Miyamoto M, Li L, Kadoya M, Takahashi R, Hase R, Kaneko H, Shichinohe T, Kawarada Y, Itoh T, Morikawa $\mathrm{T}$, et al.: Immunohistochemical analysis of nuclear survivin expression in esophageal squamous cell carcinoma. Dis Esophagus: Offic J Int Soc Dis Esophagus / ISDE 2006, 19:355-359.

46. Rosato A, Pivetta M, Parenti A, Iaderosa GA, Zoso A, Milan G, Mandruzzato S, Del Bianco P, Ruol A, Zaninotto G, Zanovello P: Survivin in esophageal cancer: An accurate prognostic marker for squamous cell carcinoma but not adenocarcinoma. Int J Cancer 2006, 119:1717-1722.

47. Hsu KF, Lin CK, Yu CP, Tzao C, Lee SC, Lee YY, Tsai WC, Jin JS: Cortactin, fascin, and survivin expression associated with clinicopathological parameters in esophageal squamous cell carcinoma. Dis Esophagus: Offic J Int Soc Dis Esophagus / ISDE 2009, 22:402-408.

48. Hoffmann AC, Vallbohmer D, Grimminger P, Metzger R, Prenzel KL, Hoelscher AH, Brabender J: Preoperative survivin mRNA detection in peripheral blood is an independent predictor of outcome in esophageal carcinoma. Pharmacogenomics 2010, 11:341-347.

49. Takeno S, Yamashita S, Takahashi Y, Ono K, Kamei M, Moroga T, Kawahara K: Survivin expression in oesophageal squamous cell carcinoma: its prognostic impact and splice variant expression. Eur J Cardiothoracic Surg: Offic J Eur Assoc Cardio-thoracic Surg 2010, 37:440-445.

50. Sarbia M, Stahl M, zur Hausen A, Zimmermann K, Wang L, Fink U, Heep H, Dutkowski P, Willers R, Muller W, et al:: Expression of p21WAF1 predicts outcome of esophageal cancer patients treated by surgery alone or by combined therapy modalities. Clin Canc Res Offic J Am Assoc Canc Res 1998, 4:26152623.

51. Hirai T, Kuwahara M, Yoshida K, Osaki A, Toge T: The prognostic significance of p53, p21 (Waf1/Cip1), and cyclin D1 protein expression in esophageal cancer patients. Anticancer Res 1999, 19:4587-4591.

52. Natsugoe S, Nakashima S, Matsumoto M, Xiangming C, Okumura H, Kijima F, Ishigami S, Takebayashi Y, Baba M, Takao S, Aikou T: Expression of p21WAF1/ Cip1 in the p53-dependent pathway is related to prognosis in patients with advanced esophageal carcinoma. Clin Cancer Res 1999, 5:2445-2449.

53. Nita $M E$, Nagawa $H$, Tominaga $O$, Tsuno $N$, Hatano K, Kitayama J, Tsuruo T, Domene CE, Muto T: p21Waf1/Cip1 expression is a prognostic marker in curatively resected esophageal squamous cell carcinoma, but not p27Kip1, p53, or Rb. Ann Surg Oncol 1999, 6:481-488.

54. Matsumoto M, Furihata M, Kurabayashi A, Sasaguri S, Araki K, Hayashi H, Ohtsuki Y: Prognostic significance of serine 392 phosphorylation in overexpressed p53 protein in human esophageal squamous cell carcinoma. Oncology 2004, 67:143-150.

55. Nakamura T, Hayashi K, Ota M, Ide H, Takasaki K, Mitsuhashi M: Expression of p21(Waf1/Cip1) predicts response and survival of esophageal cancer patients treated by chemoradiotherapy. Dis Esophagus 2004, 17:315-321.

56. Goan Y-G, Hsu H-K, Chang H-C, Chou Y-P, Chiang K-H, Cheng JT: Deregulated p21(WAF1) overexpression impacts survival of surgically resected esophageal squamous cell carcinoma patients. Ann Thorac Surg 2005, 80:1007-1016. 
57. Taghavi N, Biramijamal F, Sotoudeh M, Moaven O, Khademi H, Abbaszadegan MR, Malekzadeh R: Association of p53/p21 expression with cigarette smoking and prognosis in esophageal squamous cell carcinoma patients. World J Gastroenterol: WJG 2010, 16:4958-4967.

58. Anayama T, Furihata M, Ishikawa T, Ohtsuki Y, Ogoshi S: Positive correlation between p27Kip1 expression and progression of human esophageal squamous cell carcinoma. Int J Cancer 1998, 79:439-443.

59. Itami A, Shimada Y, Watanabe G, Imamura M: Prognostic value of p27(Kip1) and CyclinD1 expression in esophageal cancer. Oncology 1999, 57:311-317.

60. Yasunaya M, Tabira Y, Kondo K, Okuma T, Kitamura $\mathrm{N}$ : The prognostic significance of cell cycle markers in esophageal cancer after neoadjuvant chemotherapy. Dis Esophagus: Offic J Int Soc Dis Esophagus / ISDE 1999, 12:120-127.

61. Shamma A, Doki Y, Tsujinaka T, Shiozaki H, Inoue M, Yano M, Kawanishi K, Monden M: Loss of p27 (KIP1) expression predicts poor prognosis in patients with esophageal squamous cell carcinoma. Oncology 2000, 58:152-158.

62. Shiozaki H, Doki Y, Kawanishi K, Shamma A, Yano $\mathrm{M}$, Inoue $\mathrm{M}$, Monden $\mathrm{M}$ : Clinical application of malignancy potential grading as a prognostic factor of human esophageal cancers. Surgery 2000, 127:552-561.

63. Nishioka K, Doki Y, Shiozaki H, Yamamoto $H$, Tamura S, Yasuda T, Fujiwara Y, Yano M, Miyata H, Kishi $\mathrm{K}$, et al.: Clinical significance of CDC25A and CDC25B expression in squamous cell carcinomas of the oesophagus. Br J Canc 2001, 85:412-421.

64. Sarbia M, Stahl M, Fink U, Heep H, Dutkowski P, Willers R, Seeber S, Gabbert HE: Prognostic significance of cyclin D1 in esophageal squamous cell carcinoma patients treated with surgery alone or combined therapy modalities. Int J Canc 1999, 84:86-91.

65. Research Committee on Malignancy of Esophageal Cancer, Japanese Society for Esophageal Diseases: Prognostic significance of CyclinD1 and E-Cadherin in patients with esophageal squamous cell carcinoma: multiinstitutional retrospective analysis. $\mathrm{I}$ Am Coll Surg 2001, 192:708-718.

66. Ikeguchi M, Sakatani T, Ueta T, Kaibara N: Cyclin D1 expression and retinoblastoma gene protein (pRB) expression in esophageal squamous cell carcinoma. J Canc Res Clin Oncol 2001, 127:531-536.

67. Nagasawa S, Onda M, Sasajima K, Makino $H$, Yamashita K, Takubo K, Miyashita M: Cyclin D1 overexpression as a prognostic factor in patients with esophageal carcinoma. J Surg Oncol 2001, 78:208-214.

68. Shinohara M, Aoki T, Sato S, Takagi Y, Osaka Y, Koyanagi Y, Hatooka S, Shinoda M: Cell cycle-regulated factors in esophageal cancer. Dis Esophagus Offic J Int Soc Dis Esophagus / ISDE 2002, 15:149-154.
69. Guner D, Sturm I, Hemmati P, Hermann S, Hauptmann S, Wurm R, Budach V, Dorken B, Lorenz M, Daniel PT: Multigene analysis of $\mathbf{R b}$ pathway and apoptosis control in esophageal squamous cell carcinoma identifies patients with good prognosis. Int J Cancer 2003, 103:445-454.

70. Fukuchi M, Fukai Y, Kimura H, Sohda M, Miyazaki T, Nakajima M, Masuda N, Tsukada K, Kato H, Kuwano $\mathrm{H}$ : Prolyl isomerase Pin 1 expression predicts prognosis in patients with esophageal squamous cell carcinoma and correlates with cyclinD1 expression. Int J Oncol 2006, 29:329-334.

71. Takeshita H, Ichikawa D, Komatsu S, Tsujiura M, Kosuga T, Deguchi K, Konishi H, Morimura R, Shiozaki A, Fujiwara H, Okamoto $\mathrm{K}$, et al:: Prediction of CCND1 amplification using plasma DNA as a prognostic marker in oesophageal squamous cell carcinoma. $\mathrm{Br} J$ Canc 2010, 102:1378-1383. Epub 2010 Apr 1313.

72. Wang MT, Chen G, An SJ, Chen ZH, Huang ZM, Xiao P, Ben XS, Xie Z, Chen SL, Luo DL, Tang JM, et al.: Prognostic significance of cyclinD1 amplification and the co-alteration of cyclinD1/pRb/ppRb in patients with esophageal squamous cell carcinoma. Dis Esophagus 2012, 25:664-670. doi:610.1111/j.1442-2050.2011.01291.x. Epub 02011 Dec 01299.

73. Chanvitan A, Nekarda H, Casson AG: Prognostic value of DNA index, $S$-phase fraction and p53 protein accumulation after surgical resection of esophageal squamous-cell carcinomas in Thailand. Int J Canc J Int Canc 1995, 63:381-386.

74. Casson AG, Tammemagi M, Eskandarian S, Redston M, McLaughlin J, Ozcelik H: p53 alterations in oesophageal cancer: association with clinicopathological features, risk factors, and survival. Mol Pathol 1998, 51:71-79.

75. Pomp J, Davelaar J, Blom J, van Krimpen C, Zwinderman A, Quint W, Immerzeel J: Radiotherapy for oesophagus carcinoma: the impact of p53 on treatment outcome. Radiother Oncol J Eur Soc Ther Radiol Oncol 1998, 46:179-184.

76. Kanamoto A, Kato H, Tachimori Y, Watanabe H, Nakanishi Y, Kondo H, Yamaguchi H, Gotoda T, Muro $K$, Matsumura $Y$ : No prognostic significance of p53 expression in esophageal squamous cell carcinoma. $J$ Surg Oncol 1999, 72:94-98.

77. Kuwahara M, Hirai T, Yoshida K, Yamashita Y, Hihara J, Inoue H, Toge T: p53, p21(Waf1/Cip1) and cyclin D1 protein expression and prognosis in esophageal cancer. Dis Esophagus Offic J Int Soc Dis Esophagus / ISDE 1999, 12:116-119.

78. Ikeguchi M, Oka S, Gomyo Y, Tsujitani S, Maeta $\mathrm{M}$, Kaibara N: Combined analysis of p53 and retinoblastoma protein expressions in esophageal cancer. Ann Thorac Surg 2000, 70:913-917. 
79. Schneider PM, Stoeltzing O, Roth JA, Hoelscher AH, Wegerer S, Mizumoto S, Becker K, Dittler HJ, Fink U, Siewert JR: P53 mutational status improves estimation of prognosis in patients with curatively resected adenocarcinoma in Barrett's esophagus. Clin Canc Res Offic J Am Assoc Canc Res 2000, 6:3153-3158.

80. Aloia TA, Harpole DH Jr, Reed CE, Allegra C, Moore $\mathrm{MB}$, Herndon JE 2nd, D'Amico TA: Tumor marker expression is predictive of survival in patients with esophageal cancer. Ann Thorac Surg 2001, 72:859-866.

81. Berggvist AS, Bergqvist M, Brattstrom D, Hesselius P, Larsson A, Brodin O, Wagenius G: Serum p53 autoantibodies as prognostic marker in patients with oesophageal carcinoma. Anticancer Res 2001, 21:4141-4145.

82. Makoto O, Takeda A, Ting-Leig L, Shinnichi O, Hisahiro M, Yutaka F, Yoshihiro N, Kobayashi S, Gunji Y, Suzuki T, Takenori O, et al.: Prognostic significance of thymidine phosphorylase and p53 co-expression in esophageal squamous cell carcinoma. Oncol Rep 2002, 9:23-28.

83. Noguchi T, Takeno S, Shibata T, Uchida Y, Yokoyama S, Muller W: Expression of heat shock protein 70 in grossly resected esophageal squamous cell carcinoma. Ann Thorac Surg 2002, 74:222-226.

84. Shimada H, Nabeya Y, Okazumi S, Matsubara H, Funami Y, Shiratori T, Hayashi H, Takeda A, Ochiai T: Prognostic significance of serum p53 antibody in patients with esophageal squamous cell carcinoma. Surgery 2002, 132:41-47.

85. Takeno S, Noguchi T, Kikuchi R, Uchida Y, Yokoyama S, Muller W: Prognostic value of cyclin B1 in patients with esophageal squamous cell carcinoma. Cancer 2002, 94:2874-2881.

86. Gibson MK, Abraham SC, Wu TT, Burtness B, Heitmiller RF, Heath E, Forastiere A: Epidermal growth factor receptor, p53 mutation, and pathological response predict survival in patients with locally advanced esophageal cancer treated with preoperative chemoradiotherapy. Clin Canc Res Offic J Am Assoc Canc Res 2003, 9:6461-6468.

87. Ikeguchi M, Yamaguchi K, Kaibara N: Survivin gene expression positively correlates with proliferative activity of cancer cells in esophageal cancer. Tumour Biol J Int Soc Oncodevelopmental Biol Med 2003, 24:40-45.

88. Kunisaki C, Imada T, Yamada R, Hatori S, Kinbara K, Watai K, Akiyama H, Nomura M, Matsuda G, Otsuka Y, Ono $\mathrm{H}$, et al.: Prognostic factors after chemoradiotherapy for patients with inoperable esophageal squamous cell carcinoma. Hepatogastroenterology 2006, 53:366-371.

89. Hsu PK, Li AF-Y, Wang Y-C, Hsieh C-C, Huang $\mathrm{M}-\mathrm{H}$, Hsu W-H, Hsu HS: Reduced membranous betacatenin protein expression is associated with metastasis and poor prognosis in squamous cell carcinoma of the esophagus. J Thorac Cardiovasc Surg 2008, 135:1029-1035.
90. Shimada H, Shiratori T, Takeda A, Matsushita K, Okazumi S, Akutsu Y, Matsubara H, Nomura F, Ochiai T: Perioperative changes of serum p53 antibody titer is a predictor for survival in patients with esophageal squamous cell carcinoma. World J Surg 2008, 33:272-277.

91. Cheng T-H, Hsu P-K, Li AF-Y, Hung IC, Huang M-H, Hsu HS: Correlation of p53, MDM2 and p14 (ARF) protein expression in human esophageal squamous cell carcinoma. J Cancer Res Clin Oncol 2009, 135:1577-1582. Epub 2009 Jun 1572.

92. Okumura H, Kita Y, Yokomakura N, Uchikado Y, Setoyama T, Sakurai H, Omoto I, Matsumoto M, Owaki T, Ishigami S, Natsugoe S: Nuclear expression of 14-33 sigma is related to prognosis in patients with esophageal squamous cell carcinoma. Anticancer Res 2010, 30:5175-5179.

93. Yamasaki M, Miyata H, Fujiwara Y, Takiguchi S, Nakajima K, Nishida T, Yasuda T, Matsuyama J, Mori M, Doki Y: p53 genotype predicts response to chemotherapy in patients with squamous cell carcinoma of the esophagus. Ann Surg Oncol 2010, 17:634-642. Epub 2009 Nov 2026.

94. Yen C-C, Tsao Y-P, Chen PC-H, Wu Y-C, Liu J-H, Pan C-C, Liu C-Y, Tzeng C-H, Chen P-M, Chen Y-J, Lin C-H, et al.: PML protein as a prognostic molecular marker for patients with esophageal squamous cell carcinomas receiving primary surgery. J Surg Oncol 2011, 103:761-767. 710.1002/jso.21855. Epub 22011 Jan 21815.

95. Blanchard P, Quero L, Pacault V, Schlageter MH, Baruch-Hennequin V, Hennequin C: Prognostic significance of anti-p53 and anti-KRas circulating antibodies in esophageal cancer patients treated with chemoradiotherapy. BMC Canc 2012, 12:119.

96. Nakamura T, Nekarda H, Hoelscher AH, Bollschweiler E, Harbeck N, Becker K, Siewert JR, Harbec N: Prognostic value of DNA ploidy and c-erbB-2 oncoprotein overexpression in adenocarcinoma of Barrett's esophagus. Cancer 1994, 73:1785-1794.

97. Mimura K, Kono K, Hanawa M, Mitsui F, Sugai H, Miyagawa N, Ooi A, Fujii H: Frequencies of HER-2/ neu expression and gene amplification in patients with oesophageal squamous cell carcinoma. $\mathrm{Br} J$ Cancer 2005, 92:1253-1260.

98. Dreilich M, Wanders A, Brattstrom D, Bergstrom S, Hesselius P, Wagenius G, Bergqvist M: HER-2 overexpression $(3+)$ in patients with squamous cell esophageal carcinoma correlates with poorer survival. Dis Esophagus 2006, 19:224-231.

99. Rauser S, Weis R, Braselmann H, Feith M, Stein HJ, Langer R, Hutzler P, Hausmann M, Lassmann S, Siewert JR, Hofler H, et al.: Significance of HER2 lowlevel copy gain in Barrett's cancer: implications for fluorescence in situ hybridization testing in tissues. Clin Cancer Res 2007, 13:5115-5123. 
100. Berg D, Wolff C, Langer R, Schuster T, Feith M, Slotta-Huspenina J, Malinowsky K, Becker KF: Discovery of new molecular subtypes in oesophageal adenocarcinoma. PloS One 2011, 6:e23985. doi: 10.1371/journal. pone.0023985. Epub 2011 Sep 23.

101. Kato H, Nakajima M, Masuda N, Faried A, Sohda M, Fukai Y, Miyazaki T, Fukuchi M, Tsukada K, Kuwano $\mathrm{H}$ : Expression of RCAS1 in esophageal squamous cell carcinoma is associated with a poor prognosis. J Surg Oncol 2005, 90:89-94.

102. Falkenback D, Nilbert M, Oberg S, Johansson J: Prognostic value of cell adhesion in esophageal adenocarcinomas. Dis Esophagus 2008, 21:97-102.

103. Zhao XJ, Li H, Chen H, Liu Y-X, Zhang L-H, Liu S-X, Feng QL: Expression of e-cadherin and beta-catenin in human esophageal squamous cell carcinoma: relationships with prognosis. World J Gastroenterol 2003, 9:225-232.

104. Shimada Y, Hashimoto Y, Kan T, Kawamura J, Okumura T, Soma T, Kondo K, Teratani N, Watanabe G, Ino $\mathrm{Y}$, Sakamoto $\mathrm{M}$, et al.: Prognostic significance of dysadherin expression in esophageal squamous cell carcinoma. Oncology 2004. City.

105. Takeno S, Noguchi T, Fumoto S, Kimura Y, Shibata T, Kawahara K: E-cadherin expression in patients with esophageal squamous cell carcinoma: promoter hypermethylation, Snail overexpression, and clinicopathologic implications. Am J Clin Pathol 2004, 122:78-84.

106. Natsugoe S, Uchikado Y, Okumura H, Matsumoto M, Setoyama T, Tamotsu K, Kita Y, Sakamoto A, Owaki T, Ishigami S, Aikou T: Snail plays a key role in Ecadherin-preserved esophageal squamous cell carcinoma. Oncol Rep 2007, 17:517-523.

107. Setoyama T, Natsugoe S, Okumura H, Matsumoto M, Uchikado Y, Yokomakura N, Ishigami S, Aikou T: alpha-catenin is a significant prognostic factor than E-cadherin in esophageal squamous cell carcinoma. $J$ Surg Oncol 2007, 95:148-155.

108. Sasaki K, Natsugoe S, Ishigami S, Matsumoto M, Okumura H, Setoyama T, Uchikado Y, Kita Y, Tamotsu K, Sakamoto A, Owaki T, et al.: Significance of Twist expression and its association with E-cadherin in esophageal squamous cell carcinoma. J Exp Clin Cancer Res 2009, 28:158.

109. Chung Y, Law S, Kwong DL, Luk JM: Serum soluble E-cadherin is a potential prognostic marker in esophageal squamous cell carcinoma. Dis Esophagus 2011, 24:49-55. 10.1111/j.1442-2050.2010.01093.x. Epub 02010 Aug 01030.

110. Nozoe T, Saeki H, Sugimachi K: Significance of preoperative elevation of serum $\mathrm{C}$-reactive protein as an indicator of prognosis in esophageal carcinoma. Am J Surg 2001, 182:197-201.
111. Ikeda M, Natsugoe S, Ueno S, Baba M, Aikou T: Significant host- and tumor-related factors for predicting prognosis in patients with esophageal carcinoma. Ann Surg 2003, 238:197-202.

112. Nozoe T, Korenaga D, Futatsugi M, Saeki H, Maehara Y, Sugimachi K: Immunohistochemical expression of C-reactive protein in squamous cell carcinoma of the esophagus - significance as a tumor marker. Cancer Lett 2003, 192:89-95.

113. Shimada H, Nabeya Y, Okazumi S, Matsubara H, Shiratori T, Aoki T, Sugaya M, Miyazawa Y, Hayashi H, Miyazaki S, Ochiai T: Elevation of preoperative serum C-reactive protein level is related to poor prognosis in esophageal squamous cell carcinoma. J Surg Oncol 2003, 83:248-252.

114. Gockel I, Dirksen K, Messow C-M, Junginger T: Significance of preoperative $\mathrm{C}$-reactive protein as a parameter of the perioperative course and long-term prognosis in squamous cell carcinoma and adenocarcinoma of the oesophagus. World J Gastroenterol 2006, 12:3746-3750.

115. Wang C-Y, Hsieh M-J, Chiu Y-C, Li S-H, Huang H-W, Fang F-M, Huang YJ: Higher serum C-reactive protein concentration and hypoalbuminemia are poor prognostic indicators in patients with esophageal cancer undergoing radiotherapy. Radiother Oncol 2009, 92:270-275. Epub 2009 Feb 2003.

116. Zingg U, Forberger J, Rajcic B, Langton C, Jamieson GG: Association of C-reactive protein levels and long-term survival after neoadjuvant therapy and esophagectomy for esophageal cancer. J Gastrointest Surg 2010, 14:462-469. Epub 2009 Nov 2025.

117. Nakatsu T, Motoyama S, Fa Maruyama K, Usami S, Sato Y, Miura M, Hinai Y, Saito H, Minamiya Y, Murata K, Ogawa J: Tumoral CRP expression in thoracic esophageal squamous cell cancers is associated with poor outcomes. Surg Today 2012, 42:652-658. Epub 2012 Feb 2021.

118. Shimada H, Nabeya Y, Okazumi S, Matsubara H, Shiratori T, Gunji Y, Kobayashi S, Hayashi H, Ochiai T: Prediction of survival with squamous cell carcinoma antigen in patients with resectable esophageal squamous cell carcinoma. Surgery 2003, 133:486-494.

119. Kosugi S, Nishimaki T, Kanda T, Nakagawa S, Ohashi M, Hatakeyama K: Clinical significance of serum carcinoembryonic antigen, carbohydrate antigen 19-9, and squamous cell carcinoma antigen levels in esophageal cancer patients. World J Surg 2004, 28:680-685.

120. Shimada Y, Watanabe G, Kawamura J, Soma T, Okabe M, Ito T, Inoue $\mathrm{H}$, Kondo M, Mori Y, Tanaka E, Imamura $\mathrm{M}$ : Clinical significance of osteopontin in esophageal squamous cell carcinoma: comparison with common tumor markers. Oncology 2005, 68:285-292.

121. Cao M, Yie SM, Wu SM, Chen S, Lou B, He X, Ye SR, Xie K, Rao L, Gao E, Ye NY: Detection of 
survivin-expressing circulating cancer cells in the peripheral blood of patients with esophageal squamous cell carcinoma and its clinical significance. Clin Exp Metastasis 2009, 26:751-758.

122. Brattstrom D, Wagenius G, FSandstrom P, Dreilich M, Bergstrom S, Goike H, Hesselius P, Bergqvist M: Newly developed assay measuring cytokeratins 8,18 and 19 in serum is correlated to survival and tumor volume in patients with esophageal carcinoma. Dis Esophagus 2005, 18:298-303.

123. Valencia Julve J, Alonso Orduna V, Esco Baron R, Lopez-Mata $M$, Mendez Villamon A: Influence of hemoglobin levels on survival after radical treatment of esophageal carcinoma with radiotherapy. Clin Translational Oncol Offic Publ Federation Spanish Oncol Soc Nat Canc Inst Mexico 2006, 8:22-30.

124. Zhao KL, Liu G, Jiang GL, Wang Y, Zhong LJ, Yao WQ, Guo XM, Wu GD, Zhu LX, Shi XH: Association of haemoglobin level with morbidity and mortality of patients with locally advanced oesophageal carcinoma undergoing radiotherapy-a secondary analysis of three consecutive clinical phase III trials. Clin Oncol (R Coll Radiol) 2006, 18:621-627.

125. Rades D, Golke H, Schild SE, Kilic E: Impact of VEGF and VEGF receptor 1 (FLT1) expression on the prognosis of stage III esophageal cancer patients after radiochemotherapy. Strahlenther Onkol Organ Deutschen Rontgengesellschaft [et al.] 2008, 184:416-420.

126. Zenda S, Hironaka S, Boku N, Yamazaki K, Yasui H, Fukutomi A, Yoshino T, Onozawa Y, Nishimura T: Impact of hemoglobin level on survival in definitive chemoradiotherapy for T4/M1 lymph node esophageal cancer. Dis Esophagus Offic J Int Soc Dis Esophagus / ISDE 2008, 21:195-200.

127. Gould Rothberg BE, Bracken MB, Rimm DL: Tissue biomarkers for prognosis in cutaneous melanoma: a systematic review and meta-analysis. J Natl Canc Inst 2009, 101:452-474.

128. Hemingway H, Philipson P, Chen R, Fitzpatrick NK, Damant J, Shipley M, Abrams KR, Moreno S, McAllister KS, Palmer S, Kaski JC, et al.: Evaluating the quality of research into a single prognostic biomarker: a systematic review and meta-analysis of 83 studies of $\mathrm{C}$-reactive protein in stable coronary artery disease. PloS Med 2010, 7:e1000286. doi: 10.1371/journal.pmed.1000286.

129. Mrena J, Wiksten J-P, Kokkola A, Nordling S, Ristimaki A, Haglund C: COX-2 is associated with proliferation and apoptosis markers and serves as an independent prognostic factor in gastric cancer. Tumour Biol 2010, 31:1-7. 10.1007/s13277-1300910001-13274. Epub 12009 Dec 13218.

130. Chen J, Li T, Wu Y, He L, Zhang L, Shi T, Yi Z, Liu M, Pang X: Prognostic significance of vascular endothelial growth factor expression in gastric carcinoma: a meta-analysis. J Canc Res Clin Oncol 2011, 137:1799-1812.

131. Des Guetz G, Uzzan B, Nicolas P, Cucherat M, Morere JF, Benamouzig R, Breau JL, Perret GY: Microvessel density and VEGF expression are prognostic factors in colorectal cancer. Meta-analysis of the literature. Br J Canc 2006, 94:1823-1832.

132. Altieri DC: Survivin, cancer networks and pathway-directed drug discovery. Nat Rev Canc 2008, 8:61-70.

133. Lee MH, Yang HY: Negative regulators of cyclin-dependent kinases and their roles in cancers. Cell Mol life Sci: CMLS 2001, 58:1907-1922.

134. Chu IM, Hengst L, Slingerland JM: The Cdk inhibitor p27 in human cancer: prognostic potential and relevance to anticancer therapy. Nat Rev Canc 2008, 8:253-267.

135. Al-Maghrabi J, Al-Ahwal M, Buhmeida A, Syrjanen K, Sibyani A, Emam E, Ghanim A, Al-Qahtani M: Expression of cell cycle regulators p21 and p27 as predictors of disease outcome in colorectal carcinoma. J Gastrointest Canc 2012, 43:279-287.

136. Hugo $H$, Ackland ML, Blick T, Lawrence MG, Clements JA, Williams ED, Thompson EW: Epithelialmesenchymal and mesenchymal-epithelial transitions in carcinoma progression. J Cell Physiol 2007, 213:374-383.

137. Hirohashi S, Kanai Y: Cell adhesion system and human cancer morphogenesis. Canc Sci 2005, 94:575-581.

138. Gaarenstroom KN, Kenter GG, Bonfrer JMG, Korse CM, Van de Vijver MJ, Fleuren GJ, Trimbos JB: Can initial serum cyfra 21-1, SCC antigen, and TPA levels in squamous cell cervical cancer predict lymph node metastases or prognosis? Gynecol Oncol 2000, 77:164-170.

139. Hatzakis KD, Froudarakis ME, Bouros D, Tzanakis N, Karkavitsas N, Siafakas NM: Prognostic value of serum tumor markers in patients with lung cancer. Respiration 2002, 69:25-29.

140. Mahmoud FA, Rivera NI: The role of C-reactive protein as a prognostic indicator in advanced cancer. Curr Oncol Rep 2002, 4:250-255.

141. Begg CB, Mazumdar M: Operating characteristics of a rank correlation test for publication bias. Biometrics 1994, 50:1088-1101.

Received: 18 November 2014 Accepted: 27 November 2014 Published: 3 December 2014

\section{References}

1. Meilan C, Jizheng H, Zhenli Z, Jun Z, Ke L: Systematic review and metaanalysis of tumor biomarkers in predicting prognosis in esophageal cancer. BMC Cancer 2013, 13:539.

doi:10.1186/1471-2407-14-892

Cite this article as: Chen et al:: Correction - Systematic review and metaanalysis of tumor biomarkers in predicting prognosis in esophageal cancer. BMC Cancer 2014 14:892. 